\title{
A dominant-negative F-box deleted mutant of E3 ubiquitin ligase, $\beta$-TrCP1/FWD1, markedly reduces myeloma cell growth and survival in mice
}

\author{
Ramaswamy Sharma ${ }^{1, *}$, Paul J. Williams ${ }^{1, *}$, Anjana Gupta ${ }^{1}$, Brandon McCluskey $^{1}$, \\ Shylesh Bhaskaran ${ }^{1,2}$, Steve Muñoz ${ }^{1,3}$ and Babatunde O. Oyajobi ${ }^{1,4}$ \\ ${ }^{1}$ Department of Cellular and Structural Biology, University of Texas Health Science Center at San Antonio, San Antonio, TX, \\ USA \\ ${ }^{2}$ Current address: Oklahoma Medical Research Foundation, Oklahoma City, OK, USA \\ ${ }^{3}$ Current address: Vanderbilt Center for Bone Biology, Vanderbilt University Medical Center, Nashville, TN, USA \\ ${ }^{4}$ Cancer Therapy and Research Center, San Antonio, TX, USA \\ * These authors contributed equally to this work \\ Correspondence to: Babatunde O. Oyajobi, email: oyajobi@uthscsa.edu \\ Keywords: FWDI/B-TrCP1, 5TGM1, myeloma, plasmacytoma, proteasome \\ Received: December 23, $2014 \quad$ Accepted: April 30, $2015 \quad$ Published: May 12, 2015
}

This is an open-access article distributed under the terms of the Creative Commons Attribution License, which permits unrestricted use, distribution, and reproduction in any medium, provided the original author and source are credited.

\section{ABSTRACT}

Treatment of multiple myeloma with bortezomib can result in severe adverse effects, necessitating the development of targeted inhibitors of the proteasome. We show that stable expression of a dominant-negative F-box deleted $(\Delta F)$ mutant of the E3 ubiquitin ligase, SCF ${ }^{\beta-T r C P / F W D 1}$, in murine $5 T$ TM1 myeloma cells dramatically attenuated their skeletal engraftment and survival when inoculated into immunocompetent C57BL/KaLwRij mice. Similar results were obtained in immunodeficient bg-nuxid mice, suggesting that the observed effects were independent of host recipient immune status. Bone marrow stroma offered no protection for 5TGM1- $\Delta F$ cells in cocultures treated with tumor necrosis factor (TNF), indicating a cell-autonomous anti-myeloma effect. Levels of p100, IKBa, Mcl-1, ATF4, total and cleaved caspase-3, and phospho- $\beta$-catenin were elevated in 5TGM1- $\triangle \mathrm{F}$ cells whereas cIAP was downregulated. TNF also activated caspase-3 and downregulated $\mathrm{Bcl}-2$, correlating with the enhanced susceptibility of 5TGM1- $\mathrm{F}$ cells to apoptosis. Treatment of 5TGM1 tumorbearing mice with a $\beta$-TrCP1/FWD1 inhibitor, pyrrolidine dithiocarbamate (PDTC), significantly reduced tumor burden in bone. PDTC also increased levels of cleaved Mcl-1 and caspase-3 in U266 human myeloma cells, correlating with our murine data and validating the development of specific $\beta-T r C P$ inhibitors as an alternative therapy to nonspecific proteasome inhibitors for myeloma patients.

\section{INTRODUCTION}

The ubiquitin (Ub)-proteasome system is a ubiquitous, multi-catalytic, macromolecular complex responsible for the non-lysosomal targeted degradation of many proteins essential to intracellular processes, including cell cycle progression, stress response, transcriptional activation, signal transduction, apoptosis, and DNA repair [1]. Polyubiquitination of protein substrates for proteasomal degradation is a multi-step sequential process involving $\mathrm{Ub}$ activation by the E1 enzyme and its transfer to an internal lysine residue on the substrate by E2 Ub conjugases and E3 Ub ligases [2]. Because these processes are often deregulated in cancer cells, perturbations of the Ub-proteasome pathway may lead to their apoptosis. This finding has led to the clinical development of proteasome inhibitors as anticancer agents and U.S. Food and Drug Administration approval of several proteasome inhibitors for the treatment of multiple myeloma [3]. However, use of non-specific 
inhibitors of proteasomal function results in obstruction of normal protein turnover and is associated with several adverse effects, including peripheral neuropathy, thrombocytopenia, severe hepatitis, pulmonary fibrosis, and pulmonary vasculitis resulting in respiratory failure [4]. Also, acquired resistance to bortezomib therapy is increasing [5-7]. Therefore, more selective targeting of the Ub-proteasome system with fewer side effects is still required.

Of the several hundred E3 Ub ligases, the SCF (Skp1-Cullin1-F-box protein) E3 ligase has been wellcharacterized [8]. The F-box motif of SCF confers specificity to the ubiquitination process by serving as the substrate recognition/recruitment domain for the E3 ligase. Approximately $70 \mathrm{~F}$-box proteins have been identified, with $\beta$-TrCP ( $\beta$-transducin repeats-containing protein) being the most well-studied. Two paralogs of $\beta$-TrCP, $\beta$-TrCP1 and $\beta$-TrCP2, are known and these share approximately $86 \%$ identical F-boxes [9]. SCF SC- $^{\beta}$ ${ }_{\mathrm{TrCP} 1}$ is involved in the Ub-dependent degradation of several regulatory proteins including key cell cycle and apoptotic proteins such as NF- $\kappa \mathrm{B}, \mathrm{I} \kappa \mathrm{B} \alpha$, caspase-3, ATF-4 and $\beta$-catenin [10-15]. Importantly, deregulation of NF$\kappa \mathrm{B}$, a key substrate of $\mathrm{SCF}^{\beta-\operatorname{TrCP} 1}$ has been implicated in myelomagenesis and MM tumor progression $[16,17]$.

To define the role of $\mathrm{SCF}^{\beta-\operatorname{TrCP} 1}$ specifically in multiple myeloma, we generated and characterized murine 5TGM1 multiple myeloma cells stably expressing a dominant negative mutant of the murine homolog of $\beta$-TrCP1 (FWD1; F-box/WD40-repeat protein) that lacks the F-box (FWD1 $\Delta \mathrm{F}$; Figure 1A) $[10,12,18]$.
We also used a small molecule synthetic inhibitor of $\beta$-TrCP1/FWD1 Ub ligase activity to validate our studies in human myeloma cells in vitro as well as in vivo in mice. Collectively, our data point to a critical role for $\beta$-TrCP1/FWD1 in myeloma growth and progression in vivo, thereby identifying a potential target for selective inhibition of the proteasome in patients with multiple myeloma. Because genetic inhibition of both $\beta$-TrCP paralogs in mice does not result in an overt phenotype beyond reversible testicular pathology [19], targeting $\beta$-TrCP in myeloma patients is unlikely to be associated with significant side effects and offers a viable alternative to general proteasome inhibitors.

\section{RESULTS}

\section{Dominant-negative expression of $\beta$-TrCP1/FWD1 leads to accumulation of its substrates}

We initially verified the effect of dominant-negative $\Delta \mathrm{F}$ on known substrates of $\beta$-TrCP1/FWD1 in 5TGM1 myeloma cells. Immunoblotting for NF- $\mathrm{BB}$ subunits showed p100 accumulation and decreased p52 levels in 5 TGM1- $\Delta \mathrm{F}$ cells, consistent with a block in the $\beta$-TrCP1/ FWD1-mediated processing of p100 to p52 (Figure 1B; panel 1). We could not detect p105 in either cell line, but p50 was also decreased in 5 TGM1- $\Delta \mathrm{F}$ cells (Figure $1 \mathrm{~B}$;

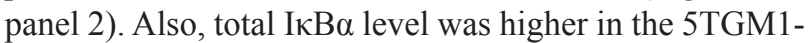
$\Delta \mathrm{F}$ cells than in $5 \mathrm{TGM} 1-\mathrm{EV}$ cells (Figure 1C), again
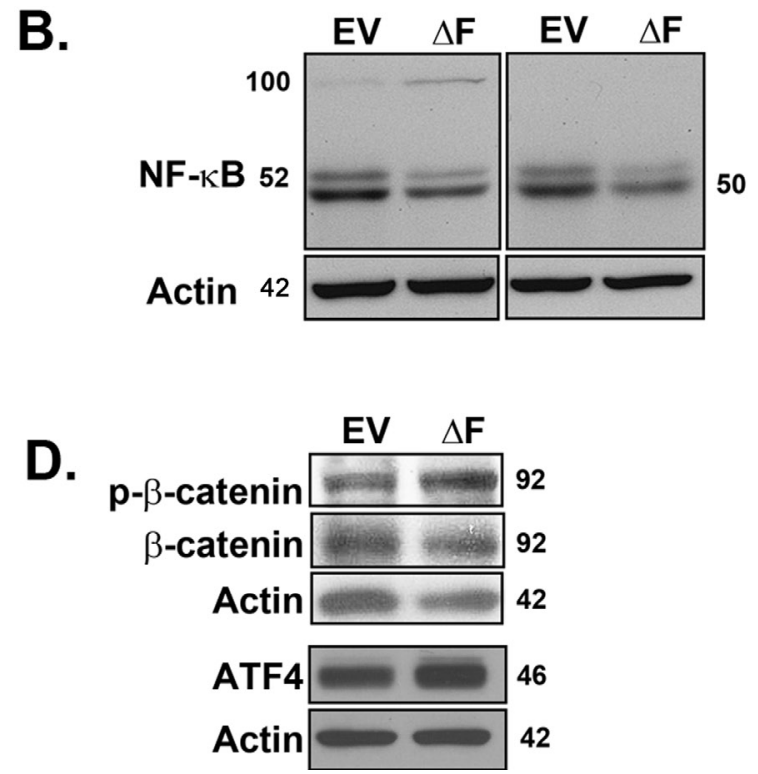

Figure 1: Dominant-negative expression of $\boldsymbol{\beta}$-TrCP1/FWD1 disrupts NF- $\kappa$ B signaling in myeloma cells. A. Representation of $\beta-\mathrm{TrCP} / \mathrm{FWD} 1 \Delta \mathrm{F}$ (adapted from [12]). B. Immunoblotting for p50/105 (left panel) and p52/p100 (right panel) in lysates obtained from untreated 5TGM1- $\triangle \mathrm{F}$ and 5TGM1-EV cells shows increased accumulation of p100 and decreased p52 levels in 5TGM1- $\Delta \mathrm{F}$ myeloma cells. C. Cells were treated with $20 \mathrm{ng} / \mathrm{ml} \mathrm{TNF-} \alpha$ and lysates prepared. Immunoblotting shows increased basal levels of total IкB $\alpha$ in 5TGM1- $\Delta \mathrm{F}$ cells. D. Untreated 5TGM1- $\Delta \mathrm{F}$ and 5TGM1-EV cells were probed for ATF4, and for total and phosphorylated forms of $\beta$-catenin. Blots were normalized to actin. 
consistent with a $\Delta \mathrm{F}$-mediated disruption in targeting of $\mathrm{I} \kappa \mathrm{B} \alpha$ for Ub-mediated proteasomal degradation. Finally, we observed an increase in the accumulation of phosphorylated $\beta$-catenin and ATF4 (Figure 1D) that are known targets of $\beta$-TrCP1/FWD1 $[12,13]$. Together, these results validate the inhibition of $\beta$-TrCP1/FWD1 in 5TGM1 cells.

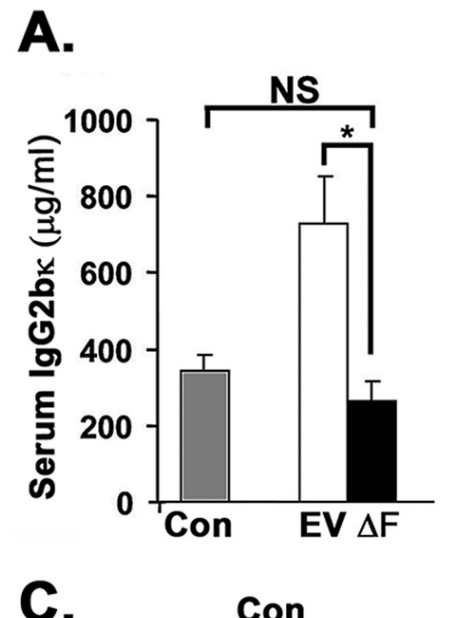

B.
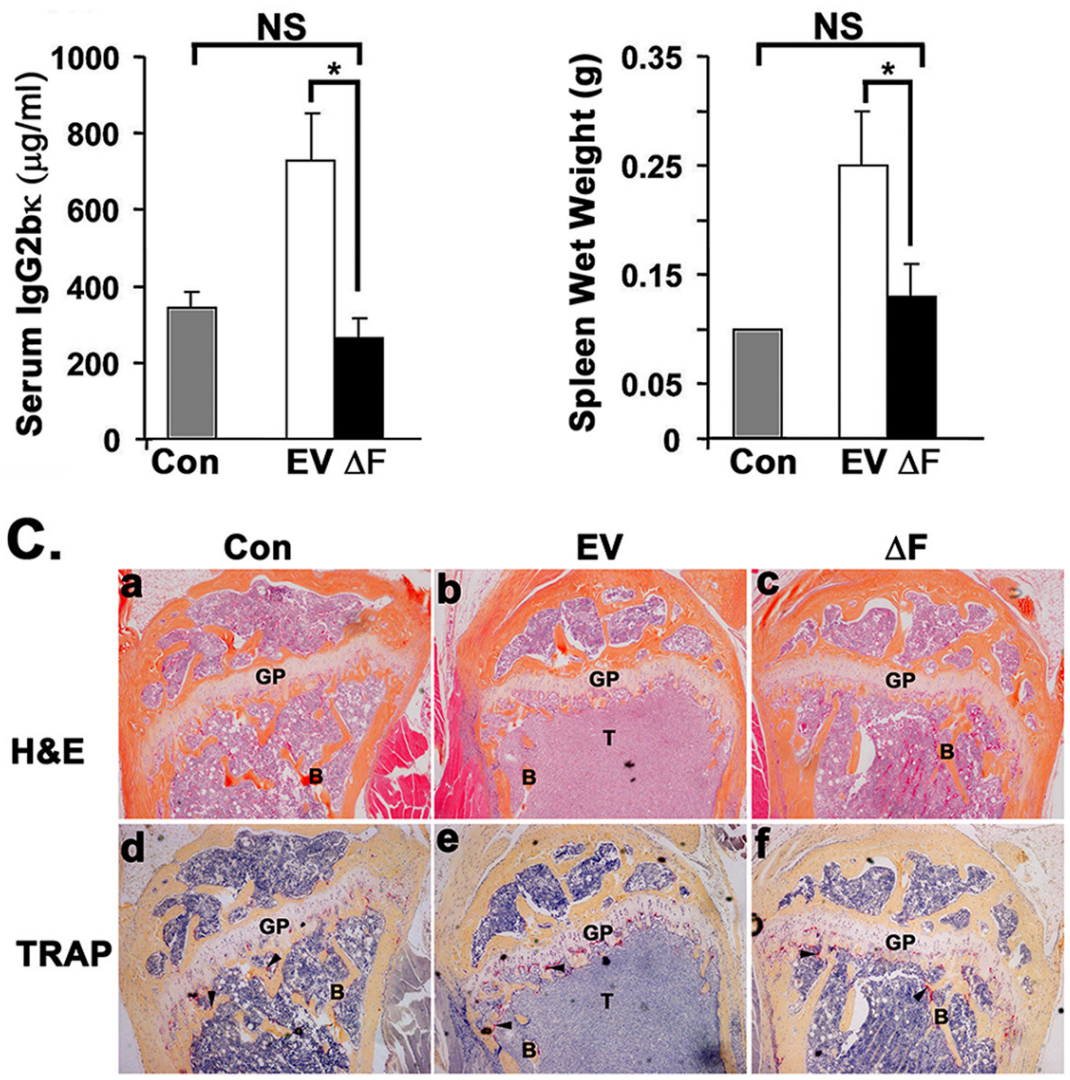

D.

\section{E.}

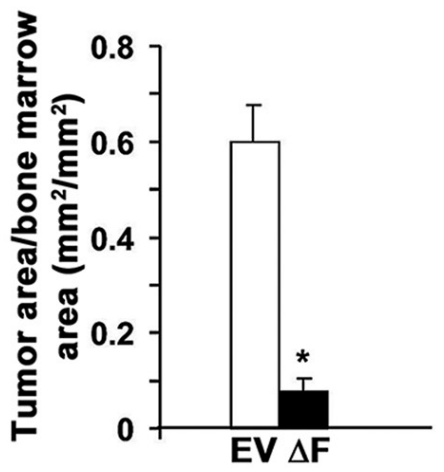

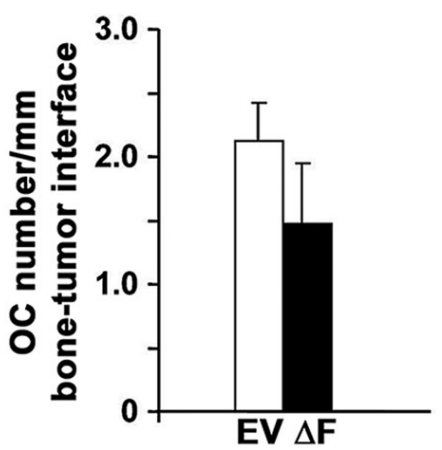

Figure 2: Tumor burden is significantly reduced in disseminated myeloma mouse model bearing 5TGM1- $\Delta$ F myeloma cells. Control (Con) represents normal non-tumor-bearing mice injected with saline ( $\mathrm{n}=4)$; EV $=5 \mathrm{TGM} 1$-EV-injected mice $(n=10) ; \Delta \mathrm{F}$

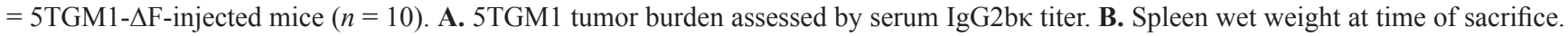
All mice had unequivocal evidence of myeloma tumor cells in spleen on hematoxylin and eosin (H\&E)-stained sections. C. Representative photo-micrographs of serial sections of proximal tibial metaphyses from control mice (a,d) and mice intravenously inoculated with 5TGM1EV $(b, e)$ or 5TGM1- $\Delta \mathrm{F}(\mathrm{c}, \mathrm{f})$ myeloma cells stained either with H\&E (a-c) or for tartrate-resistant acid phosphatase activity (TRAP; pinkishred stain) to identify multi-nucleated osteoclasts (d-f). H\&E-stained sections clearly show significantly increased tumor area in the bone marrow of mice inoculated with 5TGM1-EV mice B. as compared to control A. or 5TGM1- $\Delta \mathrm{F}$ C. mice. GP= Growth Plate; $\mathrm{B}=$ trabecular bone; $\mathrm{T}=$ tumor. Arrowheads point to osteoclasts $\mathbf{D}$. Tumor area per bone marrow area assessed by bone histomorphometry in the above $\mathrm{H} \& \mathrm{E}$-stained sections of long bones (Counts of mice with no clearly discernible myeloma tumor in at least one leg bone: EV: $2 / 10$; $\Delta \mathrm{F}$ : 8/10. E. Osteoclast density represented as counts of tartrate-resistant acid phosphatase $\left(\mathrm{TRAP}^{+}\right)$multinucleated osteoclasts $(\mathrm{OC}$; shown above) per $\mathrm{mm}$ bone tumor interface. In all cases, data represent mean \pm SEM. NS, not significantly different; ${ }^{*}, P<0.05$. 
Tumor burden is significantly reduced in mice bearing 5TGM1- $\Delta \mathrm{F}$ myeloma cells

We next used a disseminated myeloma bone disease model to determine whether dominant-negative $\Delta \mathrm{F}$ directly influences multiple myeloma cell growth and survival in vivo. Serum IgG2bא titer, a marker of overall myeloma tumor burden, was significantly lower after 30 days in mice inoculated with $5 \mathrm{TGM} 1-\Delta \mathrm{F}$ cells than in 5TGM1-EV-bearing mice (Figure 2A). This effect was

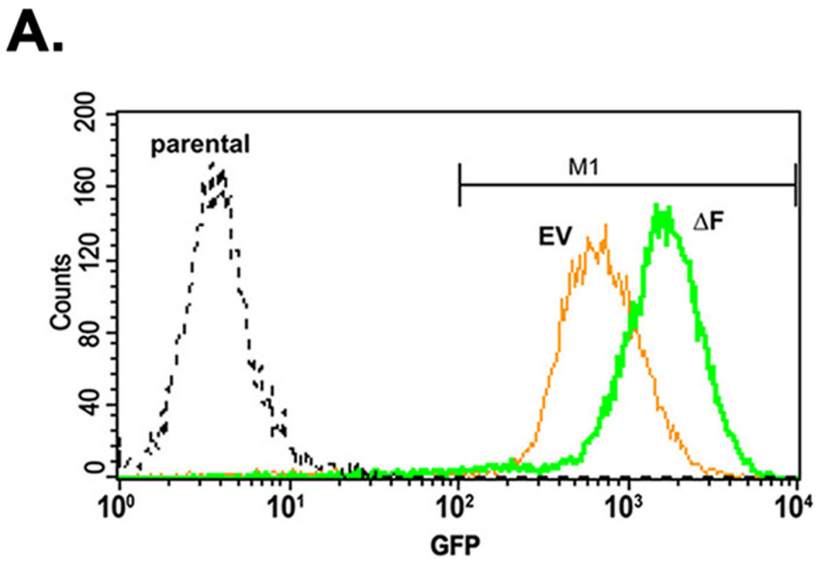

B.

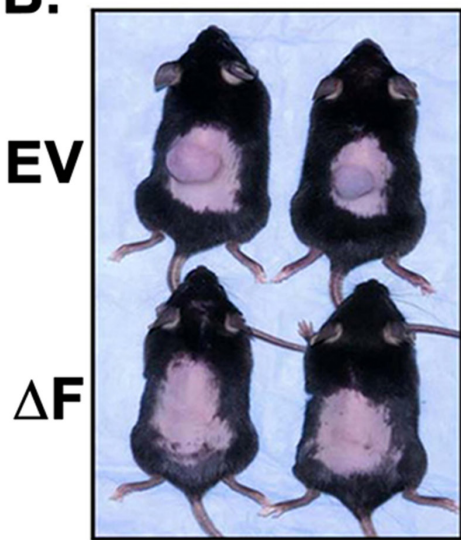

day 21

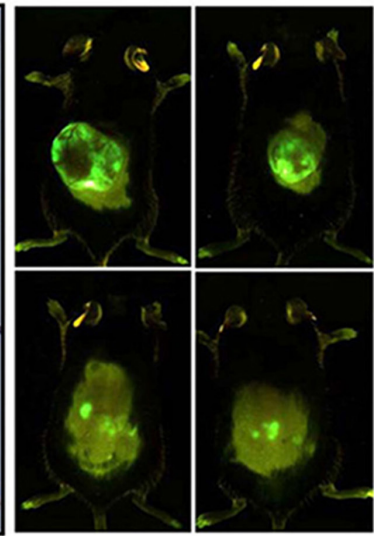

day 23

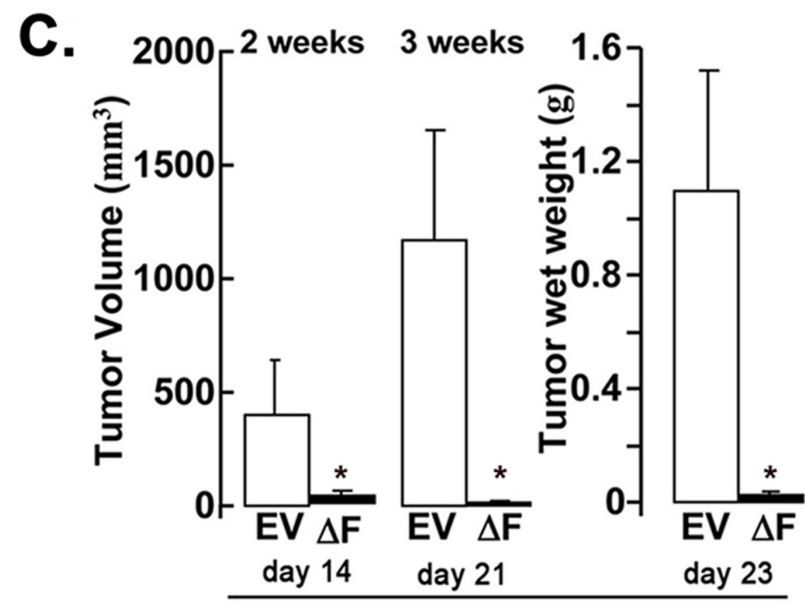

D. post tumor inoculation

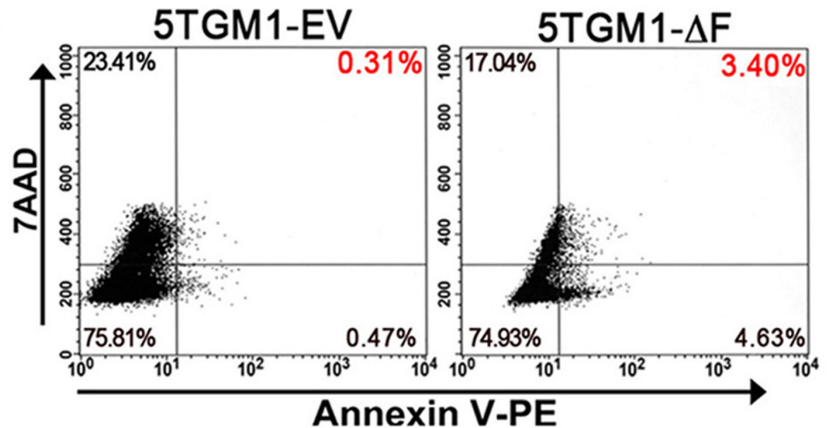

post tumor inoculation

Figure 3: $\Delta \mathbf{F}$ mutant attenuates myeloma cell growth in a cell-autonomous mode. A subcutaneous plasmacytoma model, in which tumor cells were inoculated subcutaneously in flank of syngeneic naïve mice, was used to determine the role of the bone marrow microenvironment. A. GFP expression of 5TGM1-EV and 5TGM1- $\Delta$ F cells analyzed by flow cytometry immediately before inoculation in mice. A single peak for each cell type indicates relative homogeneity of GFP expression in either population. Consistent with this observation, median GFP expression of the gated M1 populations did not differ significantly from the median GFP for all cells. B. Mice were inoculated subcutaneously with 5TGM1-EV cells $(\mathrm{EV}, n=5)$ or $5 \mathrm{TGM} 1-\Delta \mathrm{F}$ cells $(\Delta \mathrm{F}, n=5)$. Representative mice are shown (left panel); whole-body optical images of tumor-emitting green fluorescence in anesthetized live mice inoculated with above cells taken posttumor inoculation (right panel). Tumor growth in mice inoculated with 5TGM1- $\Delta \mathrm{F}$ cells (bottom) was markedly inhibited compared with those inoculated with 5TGM1-EV cells (top). C. Quantitative analysis of tumor volume (days 14 and 21 post-tumor cell inoculation) and excised tumor wet weight (at the end of the experiment; day 23 post-tumor cell inoculation). Days 14, 21 and 23 refer to the number of days after tumor cell inoculation in the flank of mice. Expression of $\Delta \mathrm{F}$ in 5TGM1 cells almost completely inhibited plasmacytoma growth in vivo. Data represent mean $\pm \mathrm{SEM} ; *, P<0.05$. D. Tumor tissue was harvested from 5TGM1-EV- and 5TGM1- $\Delta \mathrm{F}$-injected mice, disaggregated, sieved, stained with annexin V-phycoerythrin and 7-AAD, and analyzed by flow cytometry to quantify apoptotic cells (annexin $\mathrm{V}^{+}, 7-\mathrm{AAD}^{-}$; lower-right quadrant). Apoptotic cells in tumor tissue harvested from 5TGM1- $\Delta \mathrm{F}$-inoculated mice increased by $10-$ fold compared with 5TGM1-EV tumors. 
in either femur or tibia or in both leg bones were observed in 2 of 105 TGM1-EV bearing mice as compared to 8 of $105 \mathrm{TGM} 1-\Delta \mathrm{F}$-bearing mice. Consistent with these findings of reduced skeletal tumor load, a trend toward reduced osteoclast numbers per tumor interface emerged in 5TGM1- $\Delta \mathrm{F}$ mice (Figure 2C, panels d-f and Figure $2 \mathrm{E})$, manifesting as fewer radiographically detectable lytic lesions (data not shown). Histomorphometry also indicated significantly reduced myeloma tumor infiltration in spleens of 5TGM1- $\Delta \mathrm{F}$ mice. To exclude the possibility that host- initiated immune responses in immunocompetent C57BL/ KaLwRij mice influenced engraftment of $\Delta \mathrm{F}$-expressing cells, we repeated the experiments in immunodeficient $b g$ nu-xid mice. We observed similar effects in (1) tumor in bone, (2) tumor in spleen, and (3) circulating monoclonal paraprotein titers (data not shown), suggesting that effects of the $\Delta \mathrm{F}$ mutant on myeloma growth and survival in vivo are independent of perturbations in the immune compartment.
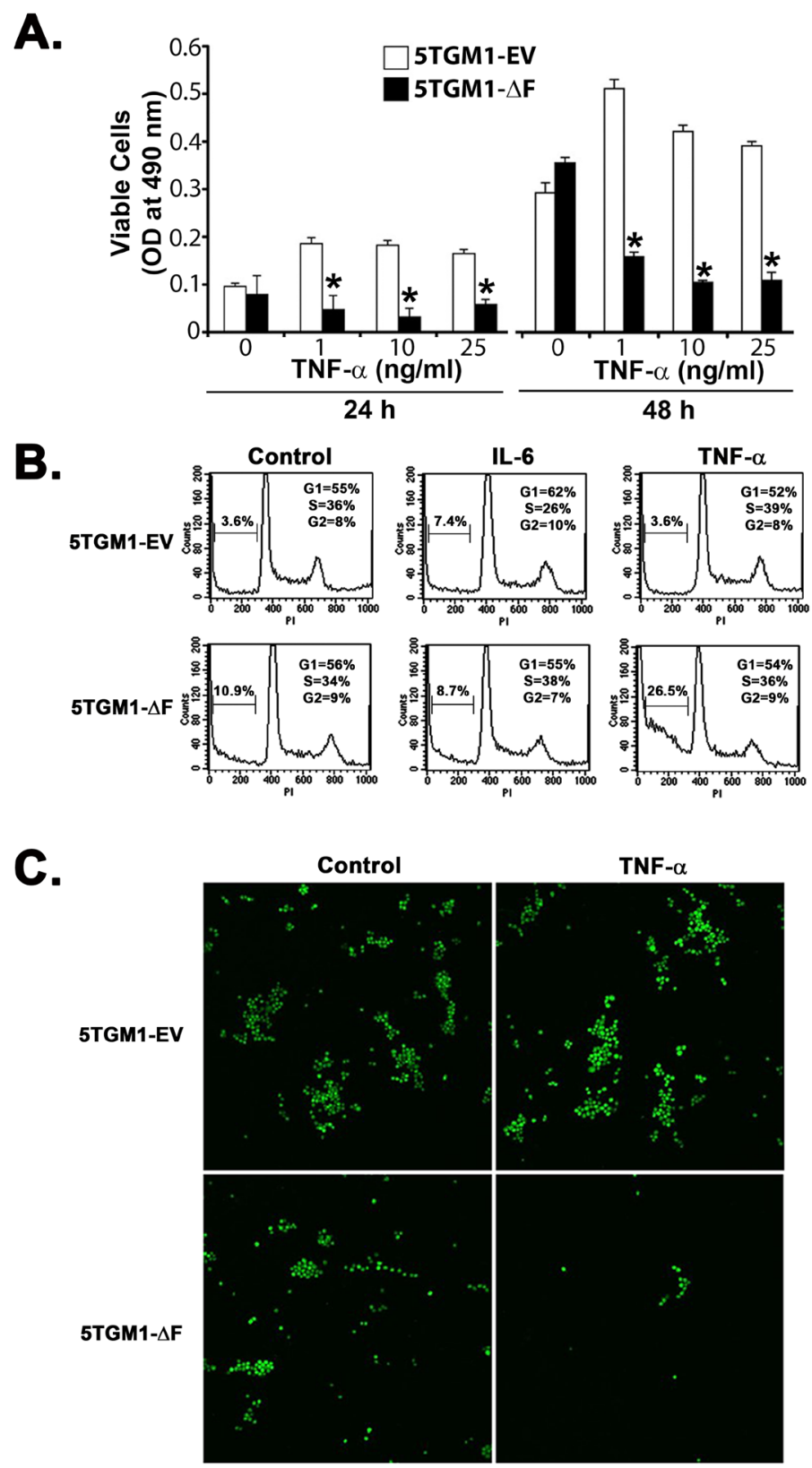

Figure 4: Bone marrow stromal cells do not protect 5TGM1- $\Delta$ F myeloma cells from TNF- $\alpha$-induced apoptosis. A. Cytotoxic and proliferative effects of TNF- $\alpha$ on 5 TGM1-EV and 5 TGM1- $\Delta$ F myeloma cells were evaluated in medium containing $2 \%$ FBS with a standard MTS assay. Data represent mean \pm SEM; * $P<0.05$. B. 5TGM1-EV or 5TGM1- $\Delta$ F cells were treated with either $100 \mathrm{ng} / \mathrm{ml}$ of IL-6 or $20 \mathrm{ng} / \mathrm{mL}$ of TNF- $\alpha$ for $24 \mathrm{~h}$, washed them in PBS, and analyzed for apoptosis by flow cytometry after staining with propidium iodide. C. 5TGM1-EV or 5TGM1- $\Delta$ F cells were grown on a layer of 14M1 BMSCs and visualized for GFP expression after treatment with $20 \mathrm{ng} / \mathrm{ml}$ of TNF- $\alpha$ for $72 \mathrm{~h}$. Viability of 5 TGM1- $\Delta \mathrm{F}$ cells decreased irrespective of the presence of BMSCs. 


\section{$\Delta \mathrm{F}$ mutant attenuates myeloma cell growth in a cell-autonomous manner}

The bone marrow microenvironment plays a critical role in myeloma cell growth and survival [20]. To determine whether the $\Delta \mathrm{F}$-induced attenuation of myeloma cell growth in bone in vivo was cell autonomous or due to tumor-induced changes in the bone marrow microenvironment, we used a subcutaneous, solitary plasmacytoma model in which tumor develops independent of marrow stroma. In this model, 5TGM1EV tumors grew exponentially two weeks after tumor cell inoculation. By contrast, growth of 5TGM1- $\Delta \mathrm{F}$ cells was almost completely inhibited, decreasing tumor volume and tumor wet weight (Figure 3B, 3C). This effect occurred despite inoculation of equal numbers of GFP-expressing cells (Figure 3A). Flow-cytometric analysis of harvested tumor cells revealed a 10-fold increase in apoptosis in $5 \mathrm{TGM} 1-\Delta \mathrm{F}$ plasmacytomas compared with 5TGM1-EV tumors (Figure 3D). Overall, these data suggest that the profound antimyeloma effect of the dominant-negative $\mathrm{FWD} 1 \Delta \mathrm{F}$ is most likely independent of local signals emanating from the bone marrow microenvironment.

\section{BMSCs do not protect 5TGM1- $\Delta \mathrm{F}$ myeloma cells from TNF- $\alpha$-induced apoptosis}

To begin to explore the mechanism(s) underlying the cell-autonomous effect of the FWD $1 \Delta \mathrm{F}$ mutant, we focused on TNFs secreted by multiple myeloma cells [21]. Human and murine myeloma cells, including 5TGM1 cells, secrete both TNF- $\alpha$ and TNF- $\beta$ [22-25], which can act as autocrine growth and survival factors $[25,26]$. We reasoned that continuous TNF production by 5TGM1 cells as they grow in vivo may increase their levels locally, which would in turn induce apoptosis of 5TGM1- $\Delta \mathrm{F}$ cells because of lack of NF-kB [27, 28]. Indeed, inhibition of NF- $\kappa B$ activity sensitizes B-lineage cells to the apoptosisinducing effects of TNFs [29, 30]. This behavior would be consistent with the increased apoptotic cell death observed in vivo in 5TGM1- $\Delta \mathrm{F}$ plasmacytomas in relation to the 5TGM1-EV plasmacytomas (Figure 3D). We therefore tested 5TGM1-EV and 5TGM1- $\Delta \mathrm{F}$ cells with TNF- $\alpha$ for 24 to $48 \mathrm{~h}$ and used a standard MTS assay to assess cytotoxic effects. TNF- $\alpha$ decreased viability of 5TGM1$\Delta \mathrm{F}$ in a dose- and time-dependent fashion in relation to 5TGM1-EV cells (Figure 4A); we observed a similar pattern for TNF- $\beta$ (data not shown). The apoptotic effect of low-dose TNF- $\alpha$ in 5 TGM $1-\Delta \mathrm{F}$ cells was more profound at lower cell density. Concentrations of TNF- $\alpha$ as low as $1 \mathrm{ng} / \mathrm{ml}$ induced cytotoxicity of low-density $5 \mathrm{TGM} 1-\Delta \mathrm{F}$ cells but stimulated proliferation of 5TGM1-EV cells, confirming previous data [21]. As would be expected in cells with impaired NF- $\kappa B$ activity, 5TGM1- $\Delta$ F cells were at least $2 \log$ orders more sensitive to high doses of both
TNFs than were 5TGM1-EV cells. Cell cycle analyses indicated an approximate threefold increase in apoptosis in untreated $\Delta \mathrm{F}$ cells compared with 5TGM1-EV cells (Figure 4B). Treatment with TNF- $\alpha$ further doubled apoptotic fraction compared with vehicle-treated $\Delta \mathrm{F}$ cells and increased apoptosis approximately sevenfold when compared with TNF- $\alpha$-treated 5TGM1-EV cells (Figure 4B). This effect appeared to be specific to TNF- $\alpha$ because treatment with recombinant murine interleukin 6 (IL-6) had little effect on apoptosis of 5 TGM1- $\Delta \mathrm{F}$ cells. Taken together, these data strongly suggest that TNFs may be involved in the inhibitory effect of FWD1 on myeloma survival.

In addition to supplying a tumor-permissive environment for myeloma growth, bone marrow cells play a critical role in protecting myeloma cells from apoptosis [31]. Therefore, we determined whether coculturing 5TGM1- $\Delta \mathrm{F}$ cells with $14 \mathrm{M} 1 \mathrm{BMSC}$ (isolated from a $5 \mathrm{~T}$ mouse myeloma [20]) protected them from TNF- $\alpha$ induced apoptosis. Imaging for GFP expression indicated fewer viable 5TGM1- $\Delta \mathrm{F}$ cells than 5TGM1-EV cells in vehicle-treated cocultures. Even more striking was the effect of TNF- $\alpha$; upon exposure to TNF- $\alpha$, considerable cell death occurred in 5TGM1 $\Delta \mathrm{F}$ cells but not in 5TGM1$\mathrm{EV}$ cells grown on $14 \mathrm{M} 1$ cell layers. This finding indicates that BMSCs do not protect $\Delta \mathrm{F}$ cells from the apoptosisinducing effect of TNF- $\alpha$, as would be expected with deficient NF- $\kappa$ B activity (Figures $4 \mathrm{C}$ and S1).

\section{TGM1- $\Delta$ F myeloma cells exhibit constitutive upregulation of proapoptotic factors}

Because we observed two-fold increase in TNF- $\alpha$ mediated apoptosis of $5 \mathrm{TGM} 1-\Delta \mathrm{F}$ cells in vitro (Figure 4B) and in vivo (Figure 3D), we determined the expression of known $\beta-\operatorname{TrCP} 1 / \mathrm{FWD} 1-$ regulated apoptotic proteins: Mcl-1 [32] , Bcl-2 [33] and caspase-3 [15, 34-36]. We also analyzed the expression of anti-apoptotic proteins downstream of NF-кB, including XIAP and cIAPs [37, 38]. Mcl-1 is an antiapoptotic member of the Bcl-2 family that is essential for myeloma cell survival $[39,40]$. We find increased levels of Mcl-1 in untreated $\Delta \mathrm{F}$ cells (Figure 5A), consistent with other studies that show that proteasome inhibition can lead to Mcl-1 accumulation [41]. Interestingly, an isoform of Mcl-1, Mcl-1v, that lacks 46 amino acids in its N-terminal and exhibits higher antiapoptotic potential as compared to Mcl-1 [42], appears to be downregulated in 5TGM1- $\Delta \mathrm{F}$ cells. XIAP is highly expressed in myeloma cells [43] and is induced by IL-6 and IGF-1-mediated activation of NF-kB/MAPK/PI3K pathways [44]. Similarly, cIAPs also play an important role in NF- $\mathrm{KB}$-mediated protection from TNF- $\alpha$-induced apoptosis in myeloma cells $[37,45]$. 5TGM1- $\Delta \mathrm{F}$ cells did not exhibit changes in XIAP levels; however, cIAP was significantly reduced in untreated 5 TGM1 $-\Delta \mathrm{F}$ cells 
A.

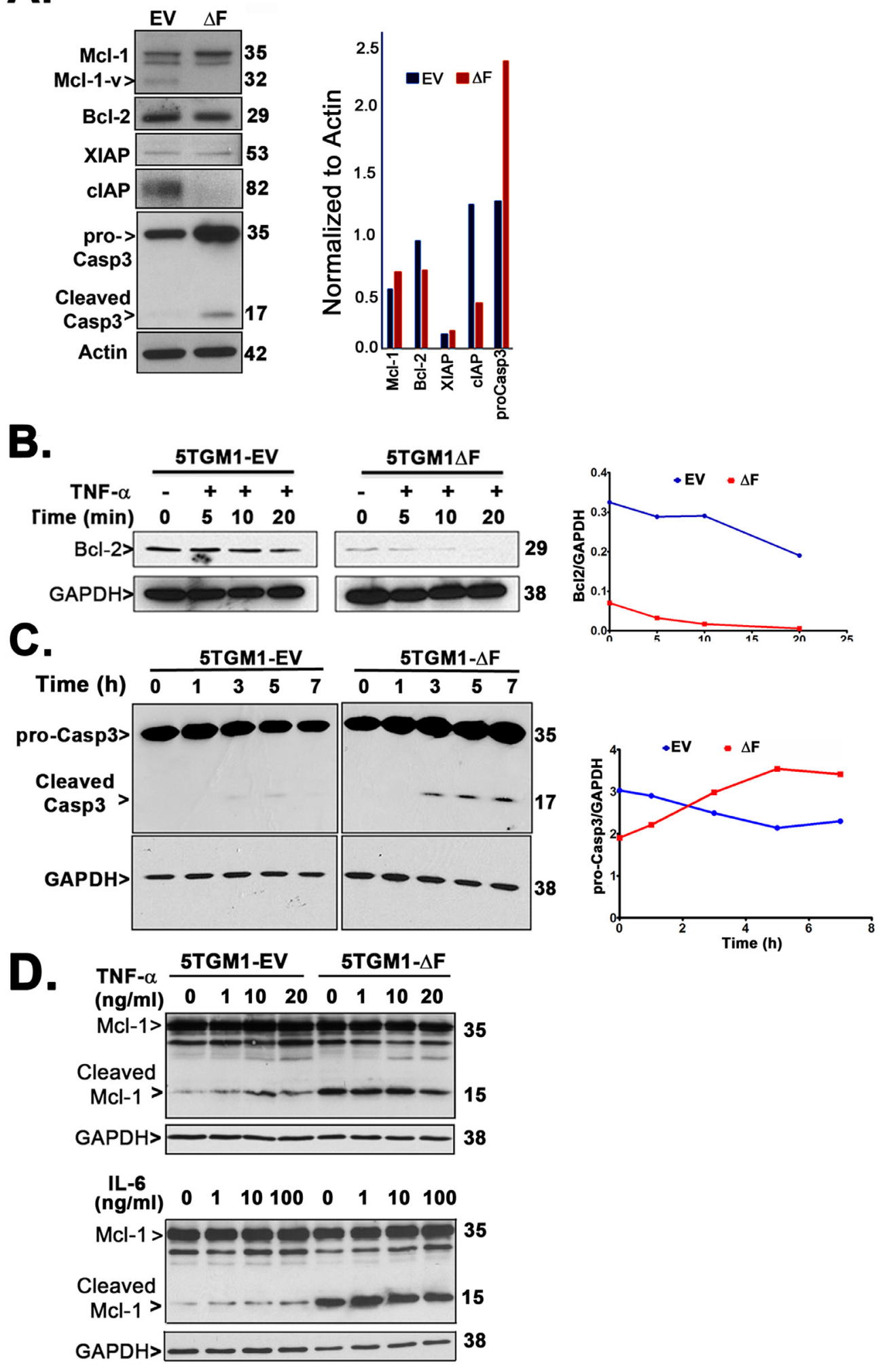

Figure 5: 5TGM1- $\Delta$ F myeloma cells exhibit constitutive upregulation of proapoptotic factors. A. Untreated 5TGM1 or 5TGM1- $\Delta$ F cells were probed for Mcl-2, Bcl-2, XIAP, cIAP and caspase-3 and normalized to actin. B. Western blotting of cell lysates shows reduced steady-state level of Bcl-2 protein in 5TGM1- $\Delta \mathrm{F}$ cells that is rapidly cleared over time after treatment with $20 \mathrm{ng} / \mathrm{ml} \mathrm{TNF}-\alpha$. C. Cells were treated with $10 \mu \mathrm{g} / \mathrm{ml}$ of cycloheximide for the indicated time points and harvested; immunoblotting of cell lysates shows significantly elevated half-life of procaspase- 3 and time-dependent increase in cleaved caspase-3 in untreated 5 TGM1- $\Delta$ F cells. D. Cells were treated for $15 \mathrm{~min}$ with TNF- $\alpha(0,1,10$, and $20 \mathrm{ng} / \mathrm{ml}$; top panel $)$ or IL- $6(0,1,10$, and $100 \mathrm{ng} / \mathrm{ml}$; bottom panel $)$ and harvested after $3 \mathrm{~h}$ into RIPA buffer followed by immunoblotting. Cleaved products of Mcl-1 are increased in untreated 5TGM1- $\Delta \mathrm{F}$ cells. 
than in 5TGM1-EV cells (Figure 5A). Bcl-2 undergoes TNF- $\alpha$-mediated dephosphorylation and Ub-mediated proteasomal degradation [33]. Bcl-2 is also a potential transcriptional target of p100 and p52 [46]. As expected, $\mathrm{Bcl}-2$ expression was lower in $5 \mathrm{TGM} 1-\Delta \mathrm{F}$ cells (Figure $5 \mathrm{~A})$, consistent with a $\Delta \mathrm{F}$-induced disruption of the p100-p52 axis. Adding TNF- $\alpha$ further reduced Bcl-2 levels in 5TGM1- $\Delta$ F cells in comparison with 5TGM1-EV cells (Figure 5B), suggesting that TNF-induced reduction in Bcl-2 levels may also contribute to apoptosis of 5TGM1$\Delta \mathrm{F}$ cells in vivo. Next, we determined if pro-apoptotic caspase-3 expression differed between 5TGM1-EV and 5 TGM1- $\Delta$ F cells. Higher levels of pro-caspase-3 as well as cleaved caspase- 3 were observed in untreated $\Delta \mathrm{F}$ cells. $\beta$-TrCP1 is known to reduce the half-life of procaspase- 3 by promoting its ubiquitin-mediated proteasomal degradation [15]. Accordingly, time course experiments showed higher levels of procaspase- 3 and cleaved caspase- 3 in cycloheximide-treated $5 \mathrm{TGM} 1-\Delta \mathrm{F}$ cells than in 5TGM1-EV cells (Figure 5C), indicating that decreased degradation lead to increased procaspase-3 accumulation in 5TGM1- $\Delta \mathrm{F}$ cells. Active caspases can cleave fulllength Mcl-1 [47, 48] to generate a proapoptotic fragment that induces Bax translocation to the mitochondria [49], thereby triggering apoptosis. Indeed, immunoblotting of untreated and TNF- $\alpha$-treated or IL-6-treated 5TGM1- $\Delta \mathrm{F}$ cell lysates showed constitutively higher levels of cleaved Mcl-1 (Figure 5D), thereby explaining their increased proclivity for apoptosis. Neither TNF- $\alpha$ nor IL-6 altered Mcl-1 levels significantly.

Inhibition of $\beta$-TrCP by PDTC significantly reduces overall tumor burden in myelomabearing mice

Our data consistently indicated that inhibition of $\beta$-TrCP by expression of the dominant-negative FWD1 $\Delta \mathrm{F}$ mutant decreased tumor burden in mice. Therefore, we investigated the antitumor efficacy of PDTC, a small-

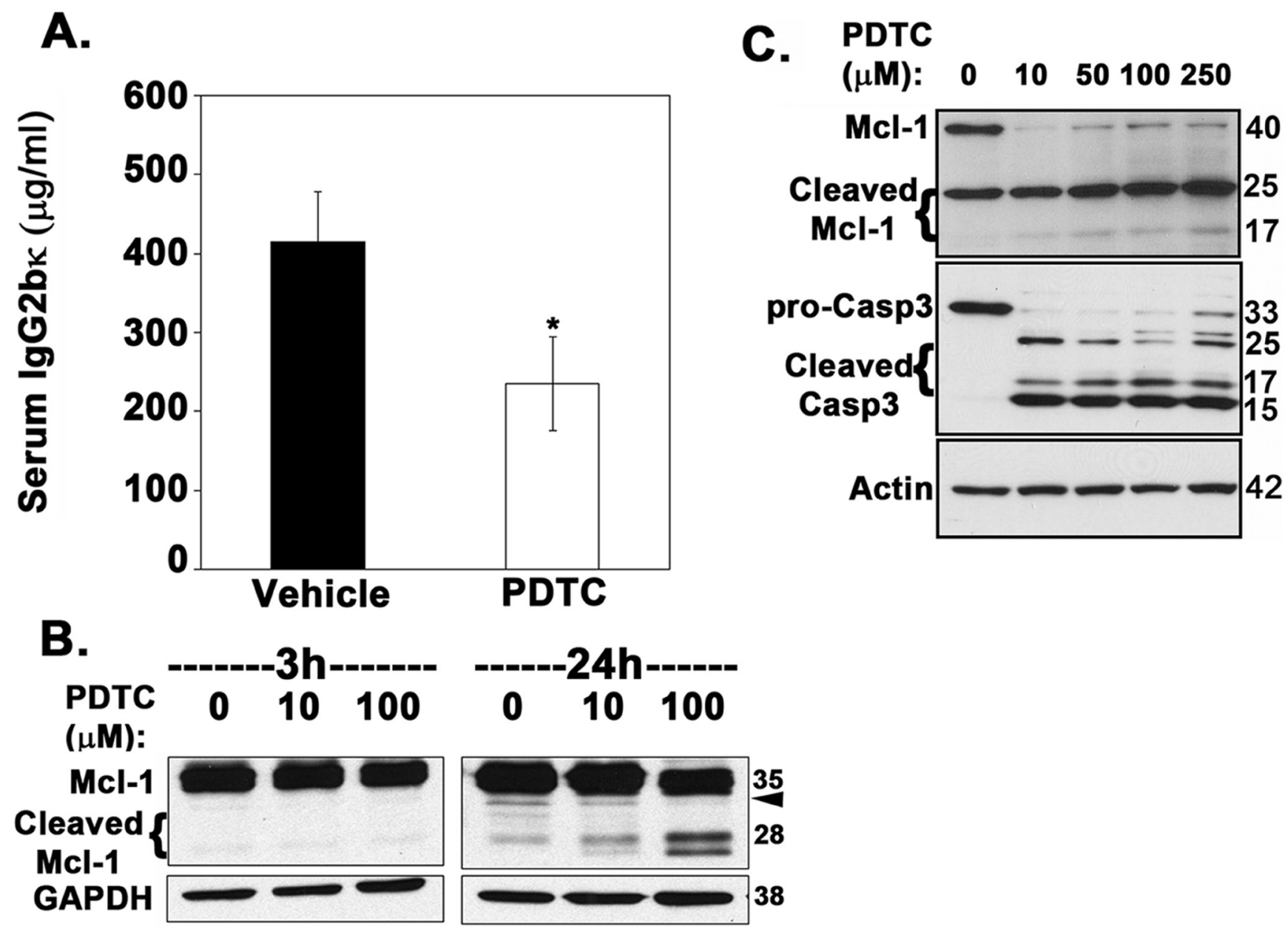

Figure 6: Inhibition of $\boldsymbol{\beta}$-TrCP by PDTC significantly reduces overall tumor burden in myeloma-bearing mice. 5TGM1bearing mice were injected with either PDTC dissolved in saline (prepared fresh as needed and injected intraperitoneally) or PBS ( $n$

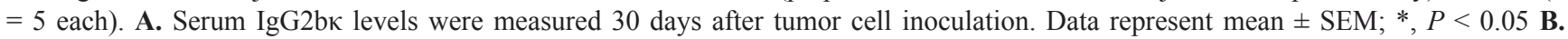
Immunoblotting of 5TGM1 lysates shows that PDTC promotes dose-dependent cleavage of Mcl-1. Arrowhead points to Mcl-1v (32 kDa) C. U266 cells were treated with 10,50, 100 and $250 \mu \mathrm{M}$ PDTC for $24 \mathrm{~h}$ and lysates probed for Mcl-1 and caspase-3. 
molecule inhibitor of $\beta$-TrCP ligase activity [50] in the 5TGM1 mouse model of myeloma. Exposing RPMI-8226 myeloma cells to PDTC results in apoptosis [51], as does treating 5TGM1 cells with PDTC (Figure S2A). Therefore, as proof of principle, we treated mice inoculated with 5TGM1 cells with PDTC. After 4 weeks, tumor burden, as

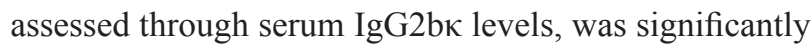
lower in PDTC-treated mice than in vehicle-treated animals (Figure 6A). To determine that PDTC was not toxic to non-tumor cells in the medullary cavity at doses $(10-50 \mu \mathrm{M})$ that kill multiple myeloma cells (Figure S2A), we performed a neonatal mouse calvarial assay. PDTC at $100 \mu \mathrm{M}$ induced a robust increase in cell proliferation and new bone formation (Figure S2B). Immunoblotting of 5TGM1 cells treated with PDTC showed dose-dependent cleavage of Mcl-1 to proapoptotic fragments and decrease in Mcl-1v levels after $24 \mathrm{~h}$ of treatment (Figure 6B), consistent with the constitutively higher levels of cleaved Mcl-1 observed in 5TGM1- $\Delta \mathrm{F}$ cells (Figure 5D). To further validate our results in human myeloma cell lines, we treated U266 cells with 10, 50, 100 and $250 \mu \mathrm{M}$ PDTC for $24 \mathrm{~h}$. Similar to 5TGM1- $\Delta \mathrm{F}$ cells, we observed an increase in cleaved Mcl-1 and cleaved caspase-3 (Figure 6C).

\section{DISCUSSION}

The dramatic response of multiple myeloma patients to bortezomib validates the Ub-proteasome system as a target for anticancer therapy. Recent approaches to decrease bortezomib side-effects include using a lower dose of bortezomib in conjunction with puromycin that triggers proteotoxic stress and synergistically enhances the tumoricidal effect of the proteasome inhibitor [52]. However, molecularly-targeted therapies that also reduce overall drug burden will be more clinically useful. Herein, we present evidence from proof-of-principle studies that selective inhibition of a single molecular target, SCF $\beta$ TrCP/FWD1, upstream of the proteasome in myeloma cells mimics the anti-tumor effect of proteasome inhibition. $\beta$-TrCP1/FWD1 mediates ubiquitination and degradation of $\mathrm{I} \kappa \mathrm{B}$, reducing total $\mathrm{I} \kappa \mathrm{B}$ levels, and we show that the dominant-negative $\Delta \mathrm{F}$ mutant causes accumulation of total $\mathrm{I} \kappa \mathrm{B}$. The $\mathrm{nfkb} 2$ gene product $\mathrm{p} 100$ and its N-terminal processed form p52 are critical for myeloma growth and survival $[16,17]$. p100 is necessary and sufficient as an $\mathrm{I} \kappa \mathrm{B}$ protein for noncanonical NF- $\kappa \mathrm{B}$ signaling [53]. In most cell types other than B-lineage cells, p100 is readily detectable, but little or no p52 is present under basal conditions [54]. By contrast, malignant plasma cells express high levels of p52 with little or no p100 present under basal conditions. Expression of the dominant-negative $\Delta \mathrm{F}$ mutant of FWD1 in 5TGM1 myeloma cells reduced p100 processing, resulting in its accumulation. p100 is proapoptotic [55], and its accumulation in $5 \mathrm{TGM} 1-\Delta \mathrm{F}$ cells may serve further to inhibit growth of the 5TGM1- $\Delta \mathrm{F}$ cells as observed in our studies. $\beta$-TrCP1/FWD1 also regulates ubiquitination of ATF4 and $\beta$-catenin [12] and the data presented herein are consistent with these results.

We also examined the effect of $\Delta \mathrm{F}$ on myeloma tumor growth and progression in vivo in two different models, a disseminated myeloma model with widespread tumor foci in the skeleton and a subcutaneous plasmacytoma model. In both models, as assessed by multiple parameters, myeloma tumor cell growth was almost completely inhibited in mice inoculated with 5TGM1- $\Delta \mathrm{F}$ cells compared with 5TGM1-EV myeloma cells. Collectively, these data strongly suggest that the profound antitumor effect of the dominant-negative $\Delta \mathrm{F}$ is mediated, in part, by tumor-secreted TNFs and is cell autonomous. Myeloma-secreted TNFs can also induce BMSCs to secrete IL-6 (the main secreted myeloma cell growth and survival factor) locally and modulate cell-cell adhesion between myeloma cells and BMSCs in the bone microenvironment [21]. However, because $\Delta F$ 's effect is just as profound in a setting devoid of BMSCs, and because our studies did not indicate any major effects of IL-6, the potential mechanism of action of TNF in this context is quite likely independent of its known paracrine effects.

Because we observed increased sensitivity of 5TGM1- $\Delta \mathrm{F}$ cells to apoptosis, we examined reported $\beta$-TrCP targets that have been implicated in apoptosis. We found that levels of the anti-apoptotic proteins, Bcl2 and cIAP, were reduced compared to empty vector controls, and conversely, we observed increased stability of procaspase- 3 as well as its increased cleavage in 5TGM1- $\Delta \mathrm{F}$ cells. Total expression of the anti-apoptotic protein, Mcl-1, increased significantly (Figure 5A), perhaps due to increased ATF4 accumulation (Figure 1D) and its consequent binding to $\mathrm{Mcl}-1$ regulatory site [56] and translational activation. However, 5TGM1- $\Delta \mathrm{F}$ cells not only show a significant decrease in the anti-apoptotic Mcl-v isoform but also exhibit an increase in cleaved, proapoptotic Mcl-1.

Taken together, our results strongly indicate that perturbation of $\beta$-TRCP/FWD1 ligase activity suffices to trigger apoptotic myeloma cell death in vivo in a cellautonomous manner, emphasizing the critical role of the tumor microenvironment in the fate of myeloma cells. Importantly, we also demonstrate an anti-tumor efficacy of PDTC, a small-molecule that has been reported to inhibit $\beta$-TrCP E3 ubiquitin ligase activity [50] in the well-established preclinical 5TGM1 mouse model of multiple myeloma that has been shown in the past to be predictive of drugs with clinical utility. Interestingly, PDTC is an analog of disulfiram, a drug used in the treatment of alcoholism that that been also shown to be toxic to human and murine myeloma cells in vitro $[51,57]$. There is increasing interest in the development of anticancer therapies that target SCF Ub ligases [58-60]. Our 
data herein clearly identify $\beta$-TrCP/FWD1 as one such selective target in the Ub-proteasome pathway that could be exploited for therapeutic benefit in MM and perhaps other hematologic malignancies.

\section{MATERIALS AND METHODS}

\section{Ethics statement}

This study was carried out in strict accordance with the recommendations in the Guide for the Care and Use of Laboratory Animals of the National Institutes of Health. The protocols described below were approved by the Institutional Animal Care and Use Committee (IACUC) at The University of Texas Health Science Center at San Antonio (UTHSCSA). The Laboratory Animal Resource facilities at UTHSCSA are accredited by the Association for Assessment and Accreditation of Laboratory Animal Care International (AAALAC). All efforts were made to minimize suffering.

\section{Cell culture}

The 5TGM1-GFP cell line, a genetically modified subclone of 5TGM1 mouse myeloma cells from the Radl $5 \mathrm{~T} 33$ (IgG2b-secreting) myeloma previously established in our laboratory [24, 26, 61-63], stably expresses enhanced green fluorescent protein (GFP)[26] and is maintained in RPMI 1640 medium containing $10 \mathrm{mM}$ HEPES (American Type Culture Collection, Manassas, VA) and 15\% fetal calf serum (Summit Biotechnology, Fort Collins, CO). To generate 5TGM1-GFP cells stably expressing FWD $1 \Delta$ F, $5 \times 10^{5}$ cells per $60-\mathrm{mm}$ cell culture dish were plated and left overnight. Flag-tagged pcDNA3 FWD1 $\Delta \mathrm{F}$ or empty vector were then transfected into the cells using DMRIE-C reagent (Life Technologies, Grand Island, NY) and selection was performed using geneticin $(\mathrm{G} 418 ; 500 \mu \mathrm{g} / \mathrm{ml})$ to obtain $5 \mathrm{TGM} 1-\Delta \mathrm{F}$ or $5 \mathrm{TGM} 1-$ $\mathrm{EV}$ cell clones, respectively. Stable gene expression was verified by immunoblotting with an anti-Flag M2 antibody (Sigma, St. Louis, MO), as described previously [12]. U266 human myeloma cells (obtained from ATCC) were grown in RPMI 1640 medium containing 15\% fetal calf serum. To determine the effect of pyrrolidone dithiocarbamate (PDTC; Sigma Chemicals, St. Louis, $\mathrm{MO})$, cells were plated at $0.4 \times 10^{6}$ cells in T-25 flasks and treated with the indicated doses of PDTC (dissolved in DMSO) for $24 \mathrm{~h}$. Cells were harvested by centrifugation, lysed with RIPA buffer, sonicated and supernatant used for immunoblotting

\section{Immunoblotting}

Whole-cell lysates prepared in radioimmuno precipitation assay (RIPA) lysis buffer containing protease inhibitors (Roche, Basel, Switzerland) were resolved on $10 \%$ or $13 \%$ polyacrylamide gels and transferred to a polyvinylidene difluoride membrane. Membranes were blocked with $5 \%$ milk in Tris-buffered saline containing $1 \%$ Tween 20 for $1 \mathrm{~h}$, incubated with primary antibodies in blocking solution overnight, and washed and incubated with appropriate secondary antibodies at room temperature for $1 \mathrm{~h}$. An enhanced chemiluminescence system (PerkinElmer, Waltham, MA) was used to visualize signals. For normalization, membranes were stripped and reprobed for actin or glyceraldehyde-3-phosphate dehydrogenase

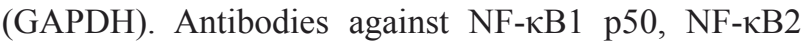
p52, Bcl-2, GAPDH, ATF4, $\beta$-catenin and actin were from Santa Cruz Biotechnology (Santa Cruz, CA); antibodies against caspase-3, phosphorylated $\beta$-catenin, $\mathrm{I} \kappa \mathrm{B} \alpha$ and XIAP were from Cell Signaling Technology (Danvers, MA). Antibody to Mcl-1 was from Rockland Immunochemicals (Gilbertsville, PA). Antibody against pan-cIAP was from R\&D Systems (Minnesota, MN).

\section{Cell viability assay}

Cell viability was assessed using a CellTiter 96 Aqueous Nonradioactive Cell Proliferation Assay (Promega, Madison, WI). In brief, cells cultured in $100 \mu \mathrm{l}$ of media in 96-well plates were pulsed with $10 \mu \mathrm{l}$ of tetrazolium salt (MTS) for the final $4 \mathrm{~h}$ of the incubation period at $37^{\circ} \mathrm{C}$ and cell viability determined by measuring absorbance at $490 \mathrm{~nm}$ on a microplate reader (BioTek Instruments, Winooski, VT). In parallel, Trypan blue-stained cells were counted using a Neubauer hemocytometer to confirm loss of viability. All experiments were repeated at least three times, with each condition tested in quadruplicate.

\section{Apoptosis and cell cycle analyses}

To quantify apoptosis, cells were washed and resuspended in ice-cold annexin $\mathrm{V}$ binding buffer containing phycoerythrin-conjugated annexin $\mathrm{V}$ and 7-amino-actinomycin D (7-AAD; BD Pharmingen, San Jose, CA) and analyzed them immediately by dual-color flow cytometry on a FACS Calibur (Becton Dickinson, San Jose, CA). Cells gated exclusively as annexin $\mathrm{V}^{+}$, $7-\mathrm{AAD}^{-}$were classified as early apoptotic and those gated as annexin $\mathrm{V}^{-}, 7-\mathrm{AAD}^{+}$as necrotic. Apoptosis was also independently confirmed using standard morphological criteria, including nuclear chromatin condensation and presence of apoptotic bodies in cells cytospun onto glass slides and stained with hematoxylin and eosin (H\&E). 
For cell cycle analysis, treated cells were washed in phosphate-buffered saline (PBS), fixed in ethanol, pelleted and labeled with $50 \mu \mathrm{g} / \mathrm{ml}$ of propidium iodide in the presence of $1 \mathrm{mg} / \mathrm{ml}$ of RNase A for $30 \mathrm{~min}$ in the dark at room temperature, followed by gating for single cells.

\section{Coculture experiments}

GFP-expressing 5TGM1-EV or 5TGM1- $\Delta \mathrm{F}(5 \times$ $10^{4}$ cells/well) were seeded onto monolayer of $14 \mathrm{M} 1$ bone marrow stromal cells (BMSCs) at approximately 60\% confluence in six-well plates and treated with recombinant murine tumor necrosis factor $\alpha$ (TNF- $\alpha$; $20 \mathrm{ng} / \mathrm{ml}$; R\&D Systems). 14M1 BMSCs were originally isolated from C57Bl/KaLwRij mice bearing 5T myeloma [24, 64, 65]. After $72 \mathrm{~h}$, spent media were replaced with fresh media (to remove floating/dead cells) and a Zeiss Axiovert $25 \mathrm{CFL}$ inverted microscope (Carl Zeiss Microscopy, Thornwood, NY) was used to image green fluorescent cells.

\section{Animal studies}

Experiments were performed with weight-matched, 6-10 weeks old female syngeneic C57BL/KaLwRij mice (Harlan, The Netherlands).

\section{Disseminated myeloma bone disease model}

$10^{6} 5 \mathrm{TGM} 1-\mathrm{EV}$ or $5 \mathrm{TGM} 1-\Delta \mathrm{F}$ cells in $200 \mu \mathrm{l}$ of PBS were inoculated into mice through tail veins. Wholeblood samples were collected for sera by retro-orbital puncture under methoxyflurane-inhaled anesthesia at baseline and then weekly after tumor inoculation. Serum

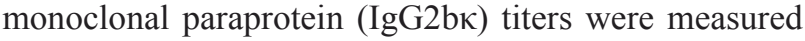
using an 'in-house' specific two-site enzyme-linked immunosorbent assay with rat anti-mouse IgG2b (Zymed Labs, San Francisco, CA) and HRP-conjugated rat antimouse IgG (BioDesign, Kennebunk, ME) as capture and detection antibodies, respectively. Experiments were terminated after 30 days. Because tumor-bearing mice in this myeloma model also develop splenomegaly, spleens were also weighed immediately after sacrifice.

To determine whether pyrrolidine dithiocarbamate (PDTC; Sigma) could inhibit tumor growth, 5TGM1 cells were inoculated into $\mathrm{C} 57 \mathrm{BL} / \mathrm{KaLwRij}$ mice through tail veins. Mice were then randomly assigned to one of two groups ( $n=5$ each) and treated with either PDTC (50 mg/ $\mathrm{kg}$ of body weight) or vehicle (PBS) daily 5 days per week

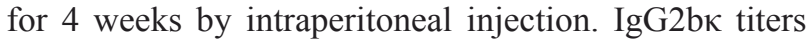
were measured in sera obtained 30 days after tumor cell inoculation.

\section{Subcutaneous plasmacytoma model}

Plasmacytomas were induced by injecting 5TGM1GFP cells in $100 \mu \mathrm{l}$ of PBS subcutaneously over flanks of naïve $\mathrm{C} 57 \mathrm{BL} / \mathrm{KaLwRij}$ mice. Tumor diameters were taken in three dimensions on days 14 and 21 post-tumor cell inoculation using an electronic caliper. Measurements of the longest perpendicular tumor diameters were used to estimate tumor volumes using the formula for volume of an ellipsoid: $4 / 3 \pi$ (width $/ 2)^{2} \times($ length $/ 2)$.

\section{Histology and histomorphometric analysis}

Skeletal tissues were fixed in $10 \%$ buffered formalin, decalcified in $14 \%$ EDTA, embedded in paraffin, and sectioned at $4 \mu \mathrm{m}$ along the midsagittal plane. Sections were stained with hematoxylin and eosin (H\&E) and analyzed for tumor infiltration of bones stereologically using an Olympus BX40 microscope (Olympus, Center Valley, PA, USA) connected to desktop computer running the OsteoMeasure histomorphometry software (Osteometrics, Atlanta, GA, USA) [24, 26, 61]. Consecutive sections of tibiae and femora were stained for tartrate-resistant acid phosphatase (TRAP) and TRAP+ multinucleated cells (nuclei $\geq 3$ ) counted as osteoclasts. Soft tissues were also embedded in paraffin and tumor volume assessed as described above. In all cases, at least three sections from non-consecutive levels were quantified and tumor volume calculated as tumor area/total bone marrow cavity area is expressed as mean $\pm \mathrm{SEM}$.

\section{Statistical analysis}

Unless otherwise stated, data were analyzed using a one-way analysis of variance with Fisher's post-hoc leastsignificant difference test and values of $P \leq 0.05$ accepted as significantly different.

\section{ACKNOWLEDGMENTS}

Dr. Kei-ichi Nakayama, Kyushu University, Japan, generously provided the Flag-tagged pcDNA3 $\mathrm{FWD} 1 \Delta \mathrm{F}$ and empty vector plasmids. We are indebted to Beryl Story (deceased), Barry Grubbs and the staff of the UTHSCSA Flow Cytometry Facility for their superb technical assistance. We are grateful to Alda Flores and Ross Garett for technical assistance with the neonatal calvarial organ cultures. We thank Drs. Julie Sterling, Claire Edwards and Ming Zhou for insightful discussions during the course of these studies, which were supported by a Career Development Award K01 CA104180 (B.O.O.) and a Program Project Grant P01 CA040035 (G.R.M. and B.O.O.) from the National Cancer Institute (NCI). The UTHSCSA Flow Cytometry Facility is supported by an NIH/NCI Cancer Center Support Grant (P30 CA054174) to the Cancer Therapy and Research Center (CTRC). This article is dedicated to the memory of late Dr. Gregory R. Mundy for his unwavering mentorship, insightful discussions, and tremendous lifetime contributions to research in multiple myeloma. 


\section{CONFLICTS OF INTEREST}

There is no conflict of interest.

\section{REFERENCES}

1. Glickman $\mathrm{MH}$ and Ciechanover A. The ubiquitinproteasome proteolytic pathway: destruction for the sake of construction. Physiol Rev. 2002; 82:373-428.

2. Sahasrabuddhe AA and Elenitoba-Johnson KS. Role of the ubiquitin proteasome system in hematologic malignancies. Immunol Rev. 2015; 263:224-239.

3. Dimopoulos MA, Richardson PG, Moreau P and Anderson KC. Current treatment landscape for relapsed and/or refractory multiple myeloma. Nat Rev Clin Oncol. 2014.

4. Kouroukis TC, Baldassarre FG, Haynes AE, Imrie K, Reece $\mathrm{DE}$ and Cheung MC. Bortezomib in multiple myeloma: systematic review and clinical considerations. Curr Oncol. 2014; $21: e 573-603$.

5. Dispenzieri A, Jacobus S, Vesole DH, Callandar N, Fonseca $\mathrm{R}$ and Greipp PR. Primary therapy with single agent bortezomib as induction, maintenance and re-induction in patients with high-risk myeloma: results of the ECOG E2A02 trial. Leukemia. 2010; 24:1406-1411.

6. Orlowski RZ and Kuhn DJ. Proteasome inhibitors in cancer therapy: lessons from the first decade. Clin Cancer Res. 2008; 14:1649-1657.

7. Richardson PG, Barlogie B, Berenson J, Singhal S, Jagannath S, Irwin D, Rajkumar SV, Srkalovic G, Alsina M, Alexanian R, Siegel D, Orlowski RZ, Kuter D, Limentani SA, Lee S, Hideshima T, et al. A phase 2 study of bortezomib in relapsed, refractory myeloma. N Engl J Med. 2003; 348:2609-2617.

8. Frescas D and Pagano M. Deregulated proteolysis by the F-box proteins SKP2 and beta-TrCP: tipping the scales of cancer. Nat Rev Cancer. 2008; 8:438-449.

9. Winston JT, Koepp DM, Zhu C, Elledge SJ and Harper JW. A family of mammalian F-box proteins. Curr Biol. 1999; 9:1180-1182.

10. Hatakeyama S, Kitagawa M, Nakayama K, Shirane M, Matsumoto M, Hattori K, Higashi H, Nakano H, Okumura $\mathrm{K}$, Onoe $\mathrm{K}$ and Good RA. Ubiquitin-dependent degradation of IkappaBalpha is mediated by a ubiquitin ligase $\mathrm{Skp} 1 / \mathrm{Cul}$ 1/F-box protein FWD1. Proc Natl Acad Sci U S A. 1999; 96:3859-3863.

11. Kanarek N and Ben-Neriah Y. Regulation of NF-kappaB by ubiquitination and degradation of the IkappaBs. Immunol Rev. 2012; 246:77-94.

12. Kitagawa M, Hatakeyama S, Shirane M, Matsumoto M, Ishida N, Hattori K, Nakamichi I, Kikuchi A and Nakayama K. An F-box protein, FWD1, mediates ubiquitin-dependent proteolysis of beta-catenin. EMBO J. 1999; 18:2401-2410.

13. Lassot I, Segeral E, Berlioz-Torrent C, Durand H, Groussin L, Hai T, Benarous R and Margottin-Goguet F.
ATF4 degradation relies on a phosphorylation-dependent interaction with the $\mathrm{SCF}$ (betaTrCP) ubiquitin ligase. Mol Cell Biol. 2001; 21:2192-2202.

14. Liang $\mathrm{C}$, Zhang $\mathrm{M}$ and Sun SC. beta-TrCP binding and processing of NF-kappaB2/p100 involve its phosphorylation at serines 866 and 870. Cell Signal. 2006; 18:1309-1317.

15. Tan M, Gallegos JR, Gu Q, Huang Y, Li J, Jin Y, Lu H and Sun Y. SAG/ROC-SCF beta-TrCP E3 ubiquitin ligase promotes pro-caspase- 3 degradation as a mechanism of apoptosis protection. Neoplasia. 2006; 8:1042-1054.

16. Annunziata CM, Davis RE, Demchenko Y, Bellamy W, Gabrea A, Zhan F, Lenz G, Hanamura I, Wright G, Xiao W, Dave S, Hurt EM, Tan B, Zhao H, Stephens O, Santra M, et al. Frequent engagement of the classical and alternative NF-kappaB pathways by diverse genetic abnormalities in multiple myeloma. Cancer Cell. 2007; 12:115-130.

17. Keats JJ, Fonseca R, Chesi M, Schop R, Baker A, Chng WJ, Van Wier S, Tiedemann R, Shi CX, Sebag M, Braggio E, Henry T, Zhu YX, Fogle H, Price-Troska T, Ahmann G, et al. Promiscuous mutations activate the noncanonical NFkappaB pathway in multiple myeloma. Cancer Cell. 2007; 12:131-144.

18. Shirane M, Hatakeyama S, Hattori K and Nakayama K. Common pathway for the ubiquitination of IkappaBalpha, IkappaBbeta, and IkappaBepsilon mediated by the F-box protein FWD1. J Biol Chem. 1999; 274:28169-28174.

19. Kanarek N, Horwitz E, Mayan I, Leshets M, Cojocaru G, Davis M, Tsuberi BZ, Pikarsky E, Pagano M and BenNeriah Y. Spermatogenesis rescue in a mouse deficient for the ubiquitin ligase $\mathrm{SCF}$ \{beta\}-TrCP by single substrate depletion. Genes Dev. 2010; 24:470-477.

20. Fowler JA, Mundy GR, Lwin ST and Edwards CM. Bone marrow stromal cells create a permissive microenvironment for myeloma development: a new stromal role for Wnt inhibitor Dkk1. Cancer Res. 2012; 72:2183-2189.

21. Hideshima T, Chauhan D, Schlossman R, Richardson P and Anderson KC. The role of tumor necrosis factor alpha in the pathophysiology of human multiple myeloma: therapeutic applications. Oncogene. 2001; 20:4519-4527.

22. Bataille R, Klein B, Jourdan M, Rossi JF and Durie BG. Spontaneous secretion of tumor necrosis factor-beta by human myeloma cell lines. Cancer. 1989; 63:877-880.

23. Borset M, Waage A, Brekke OL and Helseth E. TNF and IL-6 are potent growth factors for $\mathrm{OH}-2$, a novel human myeloma cell line. Eur J Haematol. 1994; 53:31-37.

24. Garrett IR, Dallas S, Radl J and Mundy GR. A murine model of human myeloma bone disease. Bone. 1997; 20:515-520.

25. Jourdan M, Tarte K, Legouffe E, Brochier J, Rossi JF and Klein B. Tumor necrosis factor is a survival and proliferation factor for human myeloma cells. Eur Cytokine Netw. 1999; 10:65-70.

26. Edwards CM, Edwards JR, Lwin ST, Esparza J, Oyajobi BO, McCluskey B, Munoz S, Grubbs B and Mundy 
GR. Increasing Wnt signaling in the bone marrow microenvironment inhibits the development of myeloma bone disease and reduces tumor burden in bone in vivo. Blood. 2008; 111:2833-2842.

27. Barkett M and Gilmore TD. Control of apoptosis by Rel/ NF-kappaB transcription factors. Oncogene. 1999; 18:69106924.

28. Beg AA and Baltimore D. An essential role for NF-kappaB in preventing TNF-alpha-induced cell death. Science. 1996; 274:782-784.

29. Van Antwerp DJ, Martin SJ, Verma IM and Green DR. Inhibition of TNF-induced apoptosis by NF-kappa B. Trends Cell Biol. 1998; 8:107-111.

30. Wu M, Lee H, Bellas RE, Schauer SL, Arsura M, Katz D, FitzGerald MJ, Rothstein TL, Sherr DH and Sonenshein GE. Inhibition of NF-kappaB/Rel induces apoptosis of murine B cells. EMBO J. 1996; 15:4682-4690.

31. Hao M, Zhang L, An G, Meng H, Han Y, Xie Z, Xu Y, Li C, Yu Z, Chang H and Qiu L. Bone marrow stromal cells protect myeloma cells from bortezomib induced apoptosis by suppressing microRNA-15a expression. Leuk Lymphoma. 2011; 52:1787-1794.

32. Ding Q, He X, Hsu JM, Xia W, Chen CT, Li LY, Lee DF, Liu JC, Zhong Q, Wang X and Hung MC. Degradation of Mcl-1 by beta-TrCP mediates glycogen synthase kinase 3 -induced tumor suppression and chemosensitization. Mol Cell Biol. 2007; 27:4006-4017.

33. Breitschopf K, Haendeler J, Malchow P, Zeiher AM and Dimmeler S. Posttranslational modification of Bcl-2 facilitates its proteasome-dependent degradation: molecular characterization of the involved signaling pathway. Mol Cell Biol. 2000; 20:1886-1896.

34. Chen L, Smith L, Wang $Z$ and Smith JB. Preservation of caspase-3 subunits from degradation contributes to apoptosis evoked by lactacystin: any single lysine or lysine pair of the small subunit is sufficient for ubiquitination. Molecular Pharmacol. 2003; 64:334-345.

35. Porn-Ares MI, Saido TC, Andersson T and Ares MP. Oxidized low-density lipoprotein induces calpain-dependent cell death and ubiquitination of caspase 3 in HMEC-1 endothelial cells. Biochem J. 2003; 374:403-411.

36. Suzuki Y, Nakabayashi Y and Takahashi R. Ubiquitinprotein ligase activity of $\mathrm{X}$-linked inhibitor of apoptosis protein promotes proteasomal degradation of caspase- 3 and enhances its anti-apoptotic effect in Fas-induced cell death. Proc Natl Acad Sci U S A. 2001; 98:8662-8667.

37. Mitsiades N, Mitsiades CS, Poulaki V, Chauhan D, Richardson PG, Hideshima T, Munshi N, Treon SP and Anderson KC. Biologic sequelae of nuclear factor-kappaB blockade in multiple myeloma: therapeutic applications. Blood. 2002; 99:4079-4086.

38. Ramakrishnan V, Painuly U, Kimlinger T, Haug J, Rajkumar SV and Kumar S. Inhibitor of apoptosis proteins as therapeutic targets in multiple myeloma. Leukemia.
2014; 28:1519-1528.

39. Fan F, Tonon G, Bashari MH, Vallet S, Antonini E, Goldschmidt H, Schulze-Bergkamen H, Opferman JT, Sattler M, Anderson KC, Jager D and Podar K. Targeting Mcl-1 for multiple myeloma (MM) therapy: drug-induced generation of Mcl-1 fragment Mcl-1(128-350) triggers MM cell death via c-Jun upregulation. Cancer Lett. 2014; 343:286-294.

40. Podar K, Gouill SL, Zhang J, Opferman JT, Zorn E, Tai YT, Hideshima T, Amiot M, Chauhan D, Harousseau JL and Anderson KC. A pivotal role for Mcl-1 in Bortezomibinduced apoptosis. Oncogene. 2008; 27:721-731.

41. Nencioni A, Hua F, Dillon CP, Yokoo R, Scheiermann C, Cardone MH, Barbieri E, Rocco I, Garuti A, Wesselborg S, Belka C, Brossart P, Patrone F and Ballestrero A. Evidence for a protective role of Mcl-1 in proteasome inhibitorinduced apoptosis. Blood. 2005; 105:3255-3262.

42. Kojima S, Hyakutake A, Koshikawa N, Nakagawara A and Takenaga K. MCL-1V, a novel mouse antiapoptotic MCL1 variant, generated by RNA splicing at a non-canonical splicing pair. Biochem Biophys Res Commun. 2010; 391:492-497.

43. Desplanques G, Giuliani N, Delsignore R, Rizzoli V, Bataille R and Barille-Nion S. Impact of XIAP protein levels on the survival of myeloma cells. Haematologica. 2009; 94:87-93.

44. Mitsiades CS, Mitsiades NS, Richardson PG, Munshi NC and Anderson KC. Multiple myeloma: a prototypic disease model for the characterization and therapeutic targeting of interactions between tumor cells and their local microenvironment. J Cell Biochem. 2007; 101:950-968.

45. Varfolomeev E, Goncharov T, Fedorova AV, Dynek JN, Zobel K, Deshayes K, Fairbrother WJ and Vucic D. c-IAP1 and c-IAP2 are critical mediators of tumor necrosis factor alpha (TNFalpha)-induced NF-kappaB activation. J Biol Chem. 2008; 283:24295-24299.

46. Viatour P, Bentires-Alj M, Chariot A, Deregowski V, de Leval L, Merville MP and Bours V. NF- kappa B2/p100 induces Bcl-2 expression. Leukemia. 2003; 17:1349-1356.

47. Herrant M, Jacquel A, Marchetti S, Belhacene N, Colosetti P, Luciano F and Auberger P. Cleavage of Mcl-1 by caspases impaired its ability to counteract Bim-induced apoptosis. Oncogene. 2004; 23:7863-7873.

48. Weng C, Li Y, Xu D, Shi Y and Tang H. Specific cleavage of Mcl-1 by caspase-3 in tumor necrosis factor-related apoptosis-inducing ligand (TRAIL)-induced apoptosis in Jurkat leukemia T cells. J Biol Chem. 2005; 280:1049110500 .

49. Menoret E, Gomez-Bougie P, Surget S, Trichet V, Oliver L, Pellat-Deceunynck C and Amiot M. Mcl-1(128-350) fragment induces apoptosis through direct interaction with Bax. FEBS Lett. 2010; 584:487-492.

50. Hayakawa M, Miyashita H, Sakamoto I, Kitagawa M, Tanaka H, Yasuda H, Karin M and Kikugawa K. Evidence 
that reactive oxygen species do not mediate NF-kappaB activation. EMBO J. 2003; 22:3356-3366.

51. Rickardson L, Wickstrom M, Larsson R and Lovborg H. Image-based screening for the identification of novel proteasome inhibitors. J Biomol Screen. 2007; 12:203-210.

52. Neznanov N, Komarov AP, Neznanova L, Stanhope-Baker $\mathrm{P}$ and Gudkov AV. Proteotoxic stress targeted therapy (PSTT): induction of protein misfolding enhances the antitumor effect of the proteasome inhibitor bortezomib. Oncotarget. 2011; 2:209-221.

53. Basak S, Kim H, Kearns JD, Tergaonkar V, O’Dea E, Werner SL, Benedict CA, Ware CF, Ghosh G, Verma IM and Hoffmann A. A fourth IkappaB protein within the NFkappaB signaling module. Cell. 2007; 128:369-381.

54. Betts JC and Nabel GJ. Differential regulation of NFkappaB2(p100) processing and control by amino-terminal sequences. Mol Cell Biol. 1996; 16:6363-6371.

55. Wang Y, Cui H, Schroering A, Ding JL, Lane WS, McGill G, Fisher DE and Ding HF. NF-kappa B2 p100 is a proapoptotic protein with anti-oncogenic function. Nat Cell Biol. 2002; 4:888-893.

56. Hu J, Dang N, Menu E, De Bryune E, Xu D, Van Camp B, Van Valckenborgh E and Vanderkerken K. Activation of ATF4 mediates unwanted Mcl-1 accumulation by proteasome inhibition. Blood. 2012; 119:826-837.

57. Oyajobi BO, Williams PJ, Gupta A, Trauernicht A, Zhao M, Chen D, Garrett IR and Mundy GR. Molecular mechanisms by which proteasome inhibition reduces myeloma burden in bone. J Bone Miner Res. 2002; 17(Suppl:S184).

58. Liu J, Shaik S, Dai X, Wu Q, Zhou X, Wang Z and Wei $\mathrm{W}$. Targeting the ubiquitin pathway for cancer treatment. Biochim Biophys Acta. 2014; 1855:50-60.

59. Skaar JR, Pagan JK and Pagano M. SCF ubiquitin ligasetargeted therapies. Nat Rev Drug Discov. 2014; 13(12):889903.

60. Weathington NM and Mallampalli RK. Emerging therapies targeting the ubiquitin proteasome system in cancer. J Clin Invest. 2014; 124:6-12.

61. Dallas SL, Garrett IR, Oyajobi BO, Dallas MR, Boyce BF, Bauss F, Radl J and Mundy GR. Ibandronate reduces osteolytic lesions but not tumor burden in a murine model of myeloma bone disease. Blood. 1999; 93:1697-1706.

62. Oyajobi BO, Franchin G, Williams PJ, Pulkrabek D, Gupta A, Munoz S, Grubbs B, Zhao M, Chen D, Sherry B and Mundy GR. Dual effects of macrophage inflammatory protein-1alpha on osteolysis and tumor burden in the murine 5TGM1 model of myeloma bone disease. Blood. 2003; 102:311-319.

63. Oyajobi BO, Munoz S, Kakonen R, Williams PJ, Gupta A, Wideman CL, Story B, Grubbs B, Armstrong A, Dougall WC, Garrett IR and Mundy GR. Detection of myeloma in skeleton of mice by whole-body optical fluorescence imaging. Mol Cancer Ther. 2007; 6:1701-1708.

64. Fowler JA, Mundy GR, Lwin ST and Edwards CM. Bone marrow stromal cells create a permissive microenvironment for myeloma development: a new stromal role for Wnt inhibitor Dkk1. Cancer research. 2012; 72:2183-2189.

65. Oyajobi BO, Garrett IR, Gupta A, Flores A, Esparza J, Munoz S, Zhao M and Mundy GR. Stimulation of new bone formation by the proteasome inhibitor, bortezomib: implications for myeloma bone disease. Br J Haematol. 2007; 139:434-438. 